\title{
Safe DNA-extraction Protocol Suitable for Studying Tree-fungus Interactions
}

\author{
Susanna Keriö ${ }^{1,2}$, Eeva Terhonen ${ }^{3}$ and Jared M. LeBoldus ${ }^{1,4, *}$
}

${ }^{1}$ Department of Botany and Plant Pathology, Oregon State University, 2082 Cordley Hall, Corvallis OR, 97331, USA; ${ }^{2}$ Department of Forestry and Horticulture, Connecticut Agricultural Experiment Station, 123 Huntington Street, New Haven CT, 06511, USA; ${ }^{3}$ Department of Forest Botany and Tree Physiology, Büsgen Institute, Büsgenweg 2, 37077 Göttingen, Germany; 'Department of Forest Engineering, Resources and Management, Oregon State University, 210 Snell Hall, Corvallis OR, 97331, USA

*For correspondence: jared.leboldus@oregonstate.edu

[Abstract] We present a safe and low-cost method suitable for DNA extraction from mycelium and tree tissue samples. After sample preparation, the extraction takes about $60 \mathrm{~min}$. Method performance was tested by extracting DNA from various tree tissue samples and from mycelium grown on solid and liquid media. DNA was extracted from juvenile and mature host material (Picea abies, Populus trichocarpa, Pseudotsuga menziesii) infected with different pathogens (Heterobasidion annosum, Heterobasidion parviporum, Leptographium wagenerii, Sphaerulina musiva). Additionally, DNA was extracted from pure cultures of the pathogens and several endophytic fungi. PCR success rate was $100 \%$ for young poplar material and fungal samples, and $48-72 \%$ for conifer and mature broadleaved plant samples. We recommend using $10-50 \mathrm{mg}$ of fresh sample for the best results. The method offers a safe and low-cost DNA extraction alternative to study tree-fungus interactions, and is a potential resource for teaching purposes.

Keywords: DNA extraction, Plant DNA, Fungal DNA, Forest pathology, Plant-microbe interactions, Lowcost, Non-toxic

[Background] DNA extraction is a central technique in plant-microbe interaction research and for plant disease diagnostic purposes. The abundance of plant-fungal interactions is reflected by the high numbers of cultivable strains isolated from plant samples (Arnold et al., 2001; Higgins et al., 2007; Terhonen et al., 2011). Processing of large numbers of samples for routine PCR reactions with commercial kits can be costly. Additionally, the requirement for hazardous chemicals, such as 2mercaptoethanol, chloroform, or phenol can restrict the suitability of the protocols for teaching and training purposes.

Due to high secondary metabolite content, many plant samples, and in particular tree tissues, can pose challenges for nucleic acid extraction. Current protocols for DNA extraction from recalcitrant plant tissue utilize organic solvents (chloroform, 2-mercaptoethanol) or surfactants (e.g., cetyl trimethylammonium bromide) (Porebski et al., 1997; Chiong et al., 2017; Yi et al., 2018). Despite their benefits for DNA extraction, these chemicals pose hazards to user health and the environment. Several versions of low-cost, fast, and low health risk protocols for DNA extraction exist for mycelium (Chi et al., 2009), juvenile plant tissue (Edwards et al., 1991; Lu, 2011), grains (Saini et al., 1999), and dried plant 
tissues (Chabi Sika et al., 2015). However, these methods have not been applied to study tree-fungus interactions, and many times they have been tested only on limited number of sample types. Our goal was to develop and test a safe and low-cost DNA-extraction protocol that is suitable for extracting DNA from various tree tissues and tree-associated fungal samples. After sample preparation, the extraction takes about $60 \mathrm{~min}$. The extracted DNA is suitable for PCR-based downstream applications, such as DNA-based pathogen detection with species-specific primers. Due to its safety and affordability, the method is also a potential resource for teaching and training purposes.

\section{Materials and Reagents}

A. Standard materials and reagents

1. Sterile microcentrifuge tubes, 1.5 or $2.0 \mathrm{ml}$

2. Micropipette tips: $10,200,1,000 \mu \mathrm{l}$

3. Miracloth (Calbiochem, e.g., VWR, catalog number: 475855-1)

4. Plant or fungal samples

5. Purified (RO, DI, MilliQ, Nanopure) and sterilized water

6. 100 bp DNA ladder (Jena Bioscience, catalog number: M-214S)

7. $1 \mathrm{~kb}$ DNA ladder (New England Biolabs, catalog number: N0552)

8. $\mathrm{NaCl}$

9. $\mathrm{KCl}$

10. EDTA

11. SDS

12. Tris ( $\mathrm{pH} 7.5)$

13. Polyvinypyrrolidone (PVP, CAS 900-39-8, FW 40,000, e.g., Caisson Labs, catalog number: P071-100GM)

14. Isopropanol

15. Ethanol (EtOH)

16. Extraction buffer (see Recipes)

17. Wash buffer (see Recipes)

B. Special materials and reagents for different tissue homogenization options

1. Option 1 for soft leaf tissue and mycelium: No special materials or reagents

2. Option 2 for various plant tissue and mycelium, larger than $100 \mathrm{mg}$ : Liquid nitrogen

3. Option 3 for various plant tissue and mycelium, smaller than $100 \mathrm{mg}$ : Bead beater tubes (e.g., Lysing Matrix I, MP Biomedicals, catalog number: 116918050-CF)

Note: To reduce plastic waste and save on costs, the bead beater tubes can be washed and reused (see Notes). 


\section{Equipment}

A. Standard equipment

1. Scalpels

2. Tweezers

3. Spatulas

4. Scale (e.g., Metler-Toledo, model: ML54T)

5. Micropipettes: $1,10,100,1,000 \mu \mathrm{l}$

6. Heat block (e.g., VWR, catalog number: 12621-096)

7. Vortex (e.g., VWR, catalog number: 10153-838)

8. Microcentrifuge (e.g., Eppendorf, model: 5424)

9. One of the following to heat up water: Microwave, waterbath (e.g., VWR, model: WB05), or hot plate (e.g., VWR, catalog number: NO97042-642)

10. Freezer, $-20^{\circ} \mathrm{C}$ or $-80^{\circ} \mathrm{C}$

B. Special equipment for different tissue homogenization options

1. Option 1 for soft leaf tissue and mycelium: No special equipment

2. Option 2 for various plant tissue and mycelium, more than $100 \mathrm{mg}$ :

Dewar for liquid nitrogen

Ceramic mortars and pestles

3. Option 3 for various plant tissue and mycelium, less than $100 \mathrm{mg}$ : Bead beater (e.g., Biospec, model: Mini-Beadbeater 16, catalog number: 607/607EUR)

4. For sampling xylem tissue from mature trees: chisel (e.g., Grainger, catalog number: 2AJA6) and mallet (e.g., Grainger, catalog number: 4YR61), cutting board

\section{Procedure}

A. Sample preparation: Weigh 10-50 mg of sample (see Figure 1).

1. Plant tissue: Use tweezers and scalpel to cut the sample to approximately $5 \times 5 \times 1 \mathrm{~mm}$ pieces. Smaller and thinner pieces will result in better sample quality.

2. Mycelium: Use scalpel/spatula to scrape mycelium from the surface of Petri plates, or use spatula to collect mycelium from liquid culture.

3. Xylem tissue from mature trees: Place wood sample on cutting board. Use chisel and mallet to harvest pieces of xylem tissue. Cut to $5 \times 5 \times 1 \mathrm{~mm}$ pieces with scalpel and spatula.

Note: For mycelium, minimize the amount of agar for higher DNA quality. 


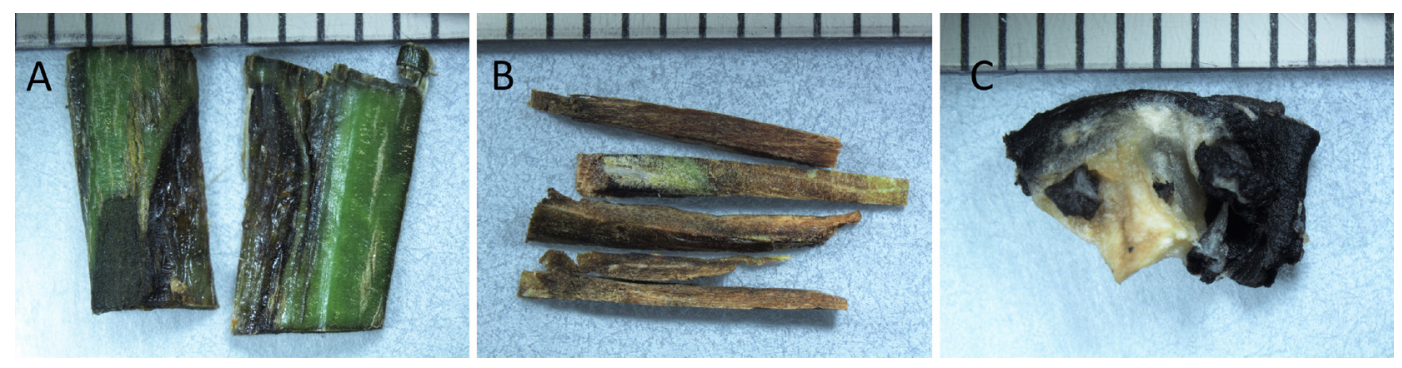

Figure 1. Examples of sample sizes for DNA extraction. A. Fresh phloem from 8-week-old Populus trichocarpa trees. Weight $20 \mathrm{mg}$. B. Fresh phloem from mature P. trichocarpa trees. Weight $15 \mathrm{mg}$. C. Fresh Leptographium wagnerii mycelium harvested from liquid malt extract cultures. Weight $20 \mathrm{mg}$. Interval between vertical lines $=1 \mathrm{~mm}$.

B. Homogenize sample and add extraction buffer

Three options are available depending on sample type. Complete homogenization is not necessary.

1. Option 1: Mycelium and soft leaf tissue
a. Place sample in a 1.5 or $2.0 \mathrm{ml}$ microcentrifuge tube.
b. Add $1 \mathrm{ml}$ extraction buffer.
c. Vortex rigorously for $20 \mathrm{~s}$.
d. Proceed to Procedure C.

2. Option 2: Various plant tissue and mycelium $\geq 50 \mathrm{mg}$ :
a. Grind sample in mortar with pestle and liquid nitrogen.
b. Transfer $10-50 \mathrm{mg}$ of homogenized sample with a spatula or by decanting to a $1.5 / 2.0 \mathrm{ml}$ microcentrifuge tube.
c. Add $1 \mathrm{ml}$ extraction buffer.
d. Vortex rigorously for $20 \mathrm{~s}$.
e. Proceed to Procedure C.

3. Option 3: Various plant tissue and mycelium $\leq 50 \mathrm{mg}$ :
a. Transfer the sample into a $2.0 \mathrm{ml}$ beat beater tube.
b. Add $1 \mathrm{ml}$ extraction buffer.
c. Process for $20 \mathrm{~s}$ in a bead beater.
d. Proceed to Procedure C.

Note: Use $1 \mathrm{ml}$ of extraction buffer per $50 \mathrm{mg}$ or less tissue. To allow sufficient vortexing, use only $1 \mathrm{ml}$ of buffer per tube.

\section{DNA extraction}

1. Heat the wash buffer in a water bath or in a beaker with warm water (approximately $65^{\circ} \mathrm{C}$ ) to dissolve any precipitants. Temperature is not critical, as long as no precipitants remain. Mix by inversion.

2. Lysis and debris elimination: Incubate the samples in extraction buffer at $65^{\circ} \mathrm{C}$ for $15 \mathrm{~min}$. Vortex once during incubation. Centrifuge at $6,000 \times \mathrm{g}$ for $10 \mathrm{~min}$. 
3. Eliminate debris: After centrifugation, transfer ca. 0.5 volume of the supernatant into a new tube. Add 1 volume of pre-heated wash buffer, and vortex samples for $20 \mathrm{~s}$. Centrifuge at 21,000 $\times \mathrm{g}$ for $10 \mathrm{~min}$.

Note: Complete debris elimination is not critical when pipetting the supernatant.

4. Precipitate: Transfer ca. 0.7 volume of supernatant into a new tube, add 0.85 volume of isopropanol (room temperature), and mix by inversion for $20 \mathrm{~s}$. Centrifuge at $21,000 \times g$ for $10 \mathrm{~min}$.

Note: Minimize transferring any debris while pipetting the supernatant.

5. Wash the pellet: Pour out the supernatant, and remove remaining supernatant by tapping the tubes upside down on a paper towel. Add $200 \mu \mathrm{l}$ of $70 \%$ ethanol, and centrifuge at $21,000 \times \mathrm{g}$ for 5 min.

Note: Consider local regulations for correct handling of isopropanol waste.

6. Dry the pellet: Pipet out the ethanol. Leave the caps open, and dry pellets in a heat block at $65^{\circ} \mathrm{C}$ for $5 \mathrm{~min}$.

Note: For faster drying, remove as much of the ethanol as possible.

7. Resuspension: Dissolve the pellet in $20-50 \mu \mathrm{l}$ of TE buffer or nuclease free water. Vortex to dissolve if needed, and centrifuge briefly to collect any droplets to the bottom of the tube. Store DNA samples at $-20^{\circ} \mathrm{C}$ or $-80^{\circ} \mathrm{C}$ until used.

Note: If the DNA pellet is not colorless or white post $70 \%$ ethanol wash, add $20-50 \mu \mathrm{l}$ of TE buffer or nuclease-free water to resuspend the DNA without disturbing the pellet. Gently pipet the liquid a few times in the tube and collect the supernatant as DNA for downstream processes. Keep the pellet until DNA is quantified. Use the DNA for PCR-based detection, or store in freezer until used.

\section{Data analysis}

\section{Analysis of protocol performance:}

A. Plant and fungal material used for DNA extractions

To test the suitability of the protocol, we extracted DNA from artificially inoculated trees, naturally infected trees, and mycelium (Table 1). The artificially inoculated samples included 8-week-old Populus trichocarpa plants spray-inoculated with Sphaerulina musiva (LeBoldus et al., 2010; Abraham et al., 2018), and 3-year-old Picea abies plants plug-inoculated with Heterobasidion sp. (Terhonen et al., 2019). The naturally infected plant samples included stem cankers on mature $P$. trichocarpa trees caused by S. musiva infection, and mature Pseudotsuga menziesii roots infected with Leptographium wageneri. Necrotic or discolored phloem or xylem samples with 10-380 mg of tissue (average $86 \mathrm{mg}$ ) were used for DNA extraction. For every sample, $1 \mathrm{ml}$ of extraction buffer was used regardless of sample weight. Fungal DNA was extracted from mycelium harvested from pure cultures (Table 1). For solid medium, either malt extract agar ( $2 \%$ malt extract, $2 \%$ agar) or KV8 agar ( $18 \%$ V8 juice, $0.2 \% \mathrm{CaCO}_{3}, 2 \%$ agar) were used. Cultures on solid medium were grown 
in ambient room temperature. For liquid medium, either malt extract medium ( $2 \%$ malt extract) or KV8 medium (18\% V8 juice, $0.2 \% \mathrm{CaCO}_{3}$ ) was used (Table 1). Cultures in liquid medium were grown in ambient room temperature on a rotary shaker (100-150 rpm). The mycelium was harvested from liquid medium by filtering through Miracloth (Calbiochem) and rinsed with DI water.

\section{B. Assessment of DNA sample quality}

DNA concentrations were measured with Nanodrop, Nanophotometer, or Qubit. PCR, quantitative real-time PCR ( $\mathrm{qPCR}$ ), agarose gel electrophoresis (Figure 2), and fungal ITS sequencing were used to evaluate sample quality. For PCR and qPCR, no-template negative controls and positive template controls were included into each run to evaluate detection reliability.

For the P. trichocarpa samples that were inoculated or naturally infected with S. musiva, we used a host-pathogen specific assay (Abraham et al., 2018). For detection of Heterobasidion species from inoculated wood samples, species-specific primers for $H$. annosum and $H$. parviporum (Hantula and Vainio, 2003) were used (Terhonen et al., 2019). For detection of $L$. wageneri from $P$. pseudotsuga roots and fungal cultures, we used Leptographium-specific primers (Schweigkofler et al., 2005). Primers for P. menziesii (Winton et al., 2002) were used to distinguish PCR-inhibition from negative samples, and to amplify DNA extracted from Douglas-fir needles.

DNA samples from Diplodia sapinea cultures were amplified with primers targeting the nuclear large subunit, elongation factor and calmodulin regions (Vilgalys and Hester, 1990; Carbone and Kohn, 1999; Grünig et al., 2007; Nelsen et al., 2011). Additionally, DNA from D. sapinea and fungal endophytes was amplified with primers ITS1-F and ITS4 for the fungal ribosomal internal transcribed spacer region (White et al., 1990; Gardes and Bruns, 1993). The PCR conditions are specified in Table 2 and primer sequences in Table 3. All PCR amplicons were visualized under UV light on 1.5\% agarose gels with StainIN ${ }^{T M}$ RED or GelRed ${ }^{T M}$ nucleic acid stains. For fungal species used for sequencing, the PCR products were purified and sequenced using the respective primers (Table 1) at Microsynth SEQLAB (Göttingen, Germany).

The effect of potential PCR inhibitors in the DNA samples on target detection was evaluated with a multiplex Taqman qPCR protocol (Abraham et al., 2018). DNA extracted with a commercial kit (DNeasy Plant Mini, Qiagen) from comparable tissue samples was used as a reference for lowinhibitor samples. Seven-point dilution series were prepared for $P$. trichocarpa (10-fold dilution series, 60-6 $\times 10^{-4} \mathrm{ng} / \mu \mathrm{l}$ ) and S. musiva DNA samples (5-fold dilution series, 50-3.2 $\left.\times 10^{-3} \mathrm{ng} / \mu \mathrm{l}\right)$ (Abraham et al., 2018) extracted with the developed method and with the commercial kit. The quantification cycle $(\mathrm{Cq})$ values for the samples from the two extraction methods were compared, to evaluate the impact of potential PCR inhibitors on target detection. 


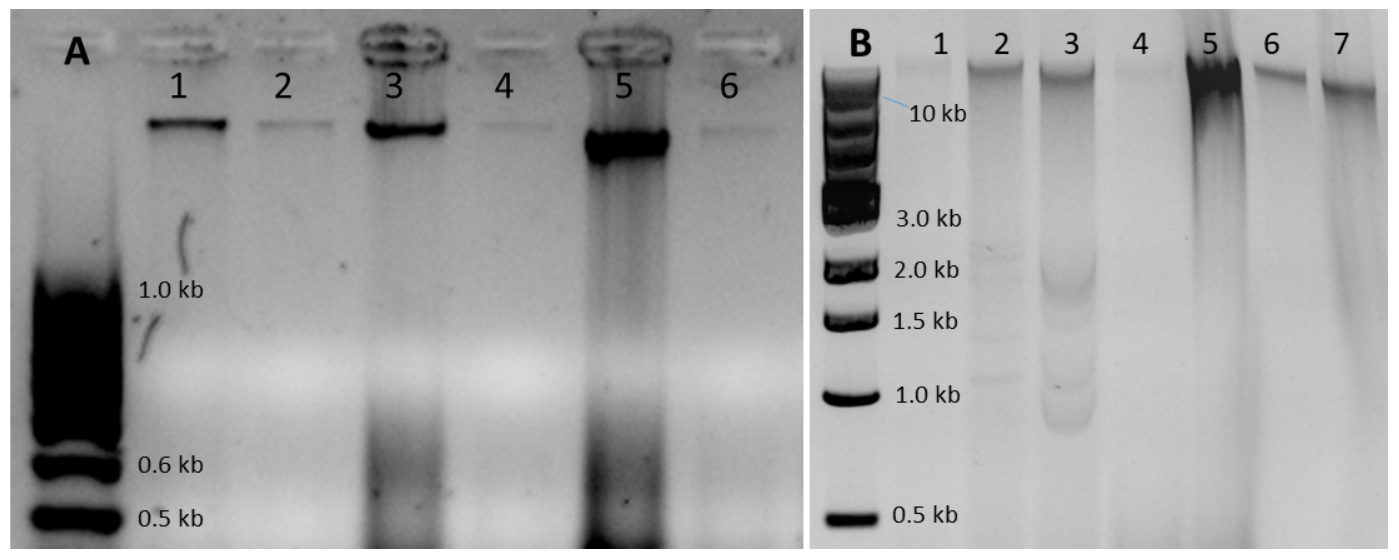

Figure 2. Examples of DNA samples extracted with the developed protocol. A. Three Diplodia sapinea DNA samples extracted from mycelium grown on malt extract agar (MEA). Lanes 1, 3, and 5: 50-500 ng of DNA. Lanes 2, 4, and 6: 10-fold dilutions of samples in lanes 1, 3, and 5. Gel: $2.0 \%$ agarose in $1 \times$ TAE, $100 \mathrm{~V}, 35 \mathrm{~min}$. Ladder: 100 bp DNA ladder. B. DNA extracted from Leptographium wagnerii mycelium from liquid malt extract (lane 1), Sphaerulina musiva mycelium grown on KV8 agar (lane 2), S. musiva grown in liquid KV8 medium (3), fresh poplar phloem (lane 4), fresh poplar leaves (lane 5), mature Douglas-fir xylem (lane 6), and fresh Douglas-fir needles (lane 7). Lanes 1-4 and 6-7: 20-100 ng DNA. Lane 5: 500 ng DNA. Gel: $1 \%$ agarose in $1 \times$ TAE, 120 V, 70 min. Ladder: 1 kb DNA ladder. 
Please cite this article as: Keriö et. al., (2020). Safe DNA-extraction Protocol Suitable for Studying Tree-fungus Interactions,Bio-protocol 10 (11): e3634. DOI:

10.21769/BioProtoc.3634.

\section{biö-protocol}

www.bio-protocol.org/e3634

Bio-protocol 10(11): e3634

DOI:10.21769/BioProtoc.3634

Table 1. Sample types extracted with the protocol, PCR success rates (\%), and number of sequenced samples

\begin{tabular}{|c|c|c|c|c|c|c|c|}
\hline Sample type & $\begin{array}{l}\text { Fungus in DNA } \\
\text { sample }\end{array}$ & $\begin{array}{l}\text { Host in DNA } \\
\text { sample }\end{array}$ & Sample description & Sample age & $\begin{array}{l}\text { Samples } \\
\text { tested }\end{array}$ & $\begin{array}{l}\text { PCR success } \\
\text { rate (\%) }\end{array}$ & Sequenced samples \\
\hline \multirow{8}{*}{$\begin{array}{l}\text { DNA extracted } \\
\text { from plant } \\
\text { material }\end{array}$} & $\begin{array}{l}\text { Heterobasidion } \\
\text { annosum }\end{array}$ & Picea abies & Inoculated phloem & 3 years & 20 & 70 & \multirow{8}{*}{ Not sequenced } \\
\hline & $\begin{array}{l}\text { Heterobasidion } \\
\text { parviporum }\end{array}$ & Picea abies & Inoculated phloem & 3 years & 20 & 25 & \\
\hline & $\begin{array}{l}\text { Leptographium } \\
\text { wageneri }\end{array}$ & $\begin{array}{l}\text { Pseudotsuga } \\
\text { menziesii }\end{array}$ & Naturally infected xylem from roots & Several years & 5 & 60 & \\
\hline & \multirow{3}{*}{ Sphaerulina musiva } & \multirow{3}{*}{$\begin{array}{l}\text { Populus } \\
\text { trichocarpa }\end{array}$} & Inoculated dry leaves & 8 weeks & 9 & 78 & \\
\hline & & & Inoculated phloem & 8 weeks & 48 & 100 & \\
\hline & & & Naturally infected phloem & Several years & 34 & 72 & \\
\hline & \multirow{2}{*}{ Not infected } & $\begin{array}{l}\text { Populus } \\
\text { trichocarpa }\end{array}$ & Leaves & 1 week & 4 & 100 & \\
\hline & & $\begin{array}{l}\text { Pseudotsuga } \\
\text { menziesii }\end{array}$ & Needles & 1 year & 6 & 100 & \\
\hline \multirow{9}{*}{$\begin{array}{l}\text { DNA extracted } \\
\text { from mycelium }\end{array}$} & $\begin{array}{l}\text { Conifer root } \\
\text { endophytes }\end{array}$ & NA & Mycelium with malt extract agar & 2 weeks & 24 & 100 & $\begin{array}{l}\text { ITS1 }{ }^{\text {a: }} 14 \text { samples ITS4 } \\
10 \text { samples }\end{array}$ \\
\hline & \multirow{4}{*}{ Diplodia sapinea } & \multirow{4}{*}{ NA } & \multirow{4}{*}{ Mycelium with malt extract agar } & 2 weeks & 39 & 100 & $\begin{array}{l}\text { ITS1 } 1^{\text {a: }} 17 \text { samples ITS } 4^{\text {a: }} \\
22 \text { samples }\end{array}$ \\
\hline & & & & 3 weeks & 22 & 100 & 22 with Pf_EF1a_R ${ }^{b}$ \\
\hline & & & & 4 weeks & 22 & 100 & 22 with CAL-737R ${ }^{\mathrm{c}}$ \\
\hline & & & & 5 weeks & 22 & 100 & 22 with $L R 6^{d}$ \\
\hline & $\begin{array}{l}\text { Leptographium } \\
\text { wageneri }\end{array}$ & NA & $\begin{array}{l}\text { Mycelium, liquid malt extract } \\
\text { medium }\end{array}$ & 3 weeks & 5 & 100 & Not sequenced \\
\hline & $\begin{array}{l}\text { Ulmus japonica } \\
\text { endophytes }\end{array}$ & NA & Mycelium with malt extract agar & 2 weeks & 61 & 100 & ITS4 $4^{\text {a: }} 61$ samples \\
\hline & \multirow{2}{*}{ Sphaerulina musiva } & \multirow{2}{*}{ NA } & Mycelium with KV8 agar & 1 week & 9 & 100 & Not sequenced \\
\hline & & & Mycelium, liquid KV8 medium & 1 week & 25 & 100 & Not sequenced \\
\hline
\end{tabular}


Please cite this article as: Keriö et. al., (2020). Safe DNA-extraction Protocol Suitable for Studying Tree-fungus Interactions,Bio-protocol 10 (11): e3634. DOI:

10.21769/BioProtoc.3634.

\section{biö-protocol}

www.bio-protocol.org/e3634

Bio-protocol 10(11): e3634

${ }^{\mathrm{a}}$ Gardes and Bruns 1993, White et al., 1990

${ }^{\text {b} G r u ̈ n i g ~ e t ~ a l ., ~} 2007$

${ }^{\circ}$ Carbone and Kohn, 1999

dVilgalys and Hester, 1990, Nelsen et al., 2011 
Please cite this article as: Keriö et. al., (2020). Safe DNA-extraction Protocol Suitable for Studying Tree-fungus Interactions,Bio-protocol 10 (11): e3634. DOI:

10.21769/BioProtoc.3634.

bĭ̈-protocol

www.bio-protocol.org/e3634

Bio-protocol 10(11): e3634

DOI:10.21769/BioProtoc.3634

Table 2. PCR conditions and primers used to test sample quality

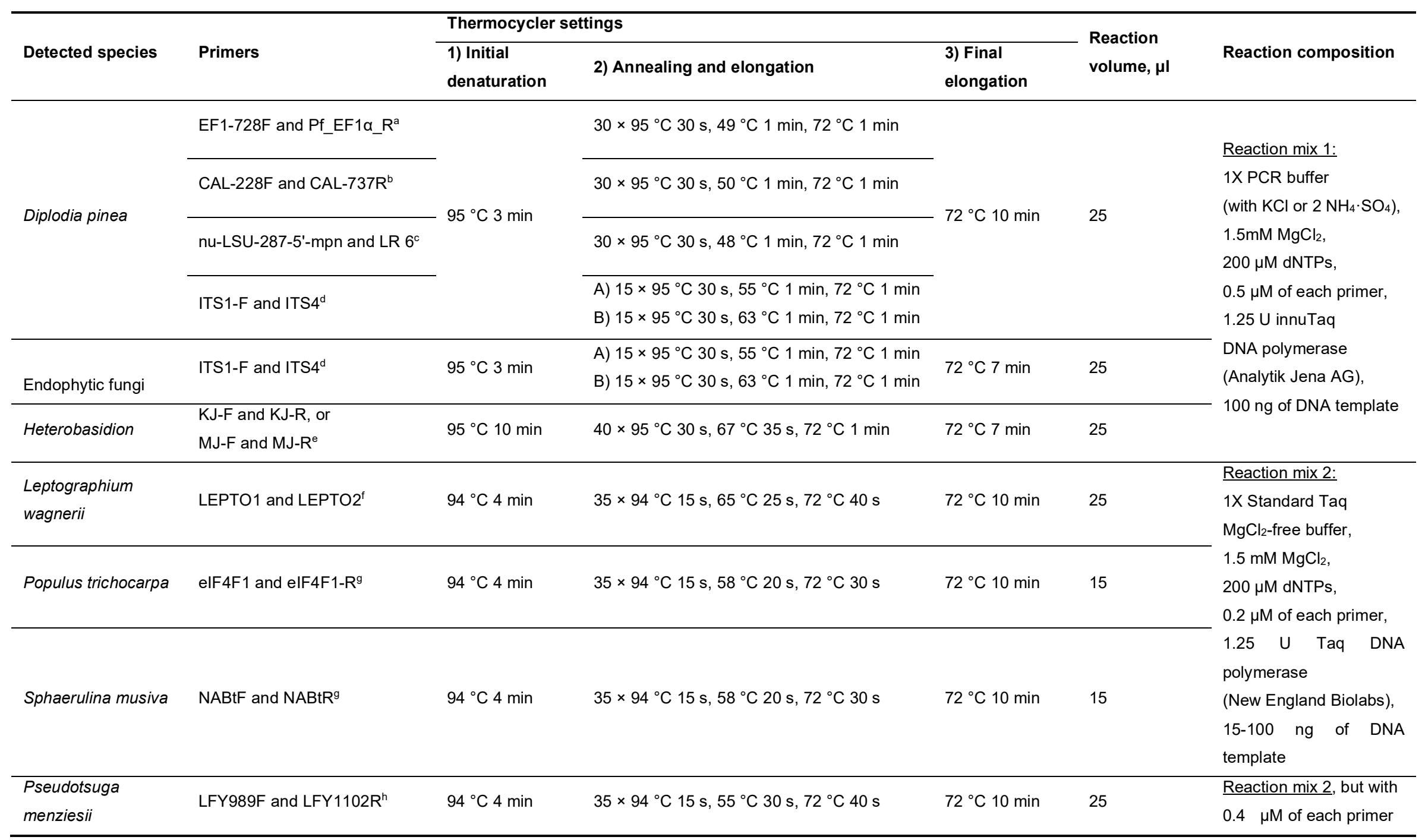

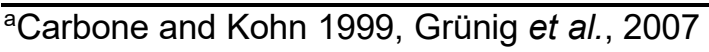

Copyright $\odot 2020$ The Authors; exclusive licensee Bio-protocol LLC. 
Please cite this article as: Keriö et. al., (2020). Safe DNA-extraction Protocol Suitable for Studying Tree-fungus Interactions,Bio-protocol 10 (11): e3634. DOI:

10.21769/BioProtoc.3634.

\section{bio-protocol}

www.bio-protocol.org/e3634

Bio-protocol 10(11): e3634

${ }^{\mathrm{b} C a r b o n e}$ and Kohn, 1999

DOI:10.21769/BioProtoc.3634

'Vilgalys and Hester, 1990, Nelsen et al., 2011

${ }^{d}$ Gardes and Brunns, 1993; White et al., 1990

eHantula and Vainio, 2003

fSchweigkofler et al., 2005

gAbraham et al., 2018

hWinton et al., 2002 
Please cite this article as: Keriö et. al., (2020). Safe DNA-extraction Protocol Suitable for Studying Tree-fungus Interactions,Bio-protocol 10 (11): e3634. DOI:

10.21769/BioProtoc.3634.

Table 3. Primer sequences used in the PCR reactions.

\begin{tabular}{|c|c|c|c|}
\hline Primer pair & Origin of DNA template & Forward primer sequence $\left(5^{\prime}->3^{\prime}\right)$ & Reverse primer sequence $\left(5^{\prime} \rightarrow 3^{\prime}\right)$ \\
\hline EF1-728F and Pf_EF1a_R ${ }^{a}$ & Diplodia pinea & CATCGAGAAGTTCGAGAAGG & GGGTTGTAGCCAACCTTCTTG \\
\hline CAL-228F and CAL-737R ${ }^{b}$ & Diplodia pinea & GAGTTCAAGGAGGCCTTCTCCC & CATCTTTCTGGCCATCATGG \\
\hline nu-LSU-287-5'-mpn and LR $6^{c}$ & Diplodia pinea & CGAGTTGTTTGGGAATGC & CGCCAGTTCTGCTTACC \\
\hline ITS1 and ITS4 ${ }^{d}$ & Fungi & CTTGGTCATTTAGAGGAAGTAA & TCCTCCGCTTATTGATATGC \\
\hline $\mathrm{KJ}-\mathrm{F}$ and $\mathrm{KJ}-\mathrm{R}$, or & Heterobasidion parviporum & CCATTAACGGAACCGACGTG & GTGCGGCTCATTCTACGCTATC \\
\hline$M J-F$ and $M J-R^{e}$ & Heterobasidion annosum & GGTCCTGTCTGGCTTTGC & CTGAAGCACACCTTGCCA \\
\hline LEPTO1 and LEPTO ${ }^{f}$ & Leptographium sp. & CAAAGACGGCAGACGCGAGTCTC & GTTCCAGGGAACTCGGAAG \\
\hline elF4F1 and elF4F1-R ${ }^{g}$ & Populus sp. & TGGGGCCTCTATTTAGCATGGAT & CTGCACCCGAAATGGGATTGACC \\
\hline NABtF and NABtR ${ }^{g}$ & Sphaerulina musiva & CGACCTGAACCACCTTGTCT & CACGGTAACAGCGCGGAACGA \\
\hline LFY989F and LFY1102R ${ }^{h}$ & Pseudotsuga menziesii & TGTTCAACATCCAGGCAATGA & TAACCGGCGCCTGAATGCTTCG \\
\hline
\end{tabular}

${ }^{a}$ Carbone and Kohn, 1999, Grünig et al., 2007

${ }^{\mathrm{b} C}$ Carbone and Kohn, 1999

'Vilgalys and Hester, 1990, Nelsen et al., 2011

${ }^{d}$ Gardes and Brunns, 1993, White et al., 1990

eHantula and Vainio, 2003

fSchweigkofler et al., 2005

gAbraham et al., 2018

hWinton et al., 2002 
C. Data analysis

Data analysis was conducted in $R$ version 3.6.1. The effect of PCR inhibitors on quantification cycle $\left(C_{q}\right)$ values was estimated using ANOVA followed by Tukey's HSD tests (Figure $3 A$ ). We visualized the contribution of sample weight, DNA concentration, and sample purity $\left(A_{260 / 280}\right.$ and $\left.A_{260 / 230}\right)$ on PCR success by plotting the results from principal component analysis (PCA) for the plant and fungal samples (Figures 3B-3D). The PCA results were visualized with the R package factoextra (Kassambara and Mundt 2017). For $P$. abies samples, necrosis length was also included in the model. Separate PCA's were computed for $P$. trichocarpa samples $(n=85), P$. abies samples $(n=$ $48)$, and fungal samples $(n=129)$. Differences in template properties between failed and successful PCR reactions within the same sample type were compared by two-sample t-tests. If necessary, data were normalized with log-transformations.

\section{Protocol performance}

All the DNA samples extracted from 8-week-old P. trichocarpa phloem inoculated with S. musiva were PCR-positive for the pathogen (Table 1). PCR amplification worked for all fungal DNA samples, and the PCR products were suitable for fungal ITS sequencing. In comparison, PCR success rate was lower for DNA samples extracted from naturally infected mature $P$. trichocarpa samples $(72 \%)$, inoculated 3-year-old $P$. abies samples (48\%), and naturally infected mature $P$. menziesii roots $(60 \%)$ (Table 1). The extraction protocol yields total DNA with the majority of the fragments larger than $10 \mathrm{~kb}$ (Figure 2). The samples are stable at least for 2 years in $-20^{\circ} \mathrm{C}$. Partial DNA fragmentation (Figure 2B) did not affect PCR performance.

Based on the comparison of $C_{q}$ values for DNA samples extracted with a commercial kit, the extracted DNA samples may contain inhibitors that can affect the accuracy of target quantification by qPCR (Figure 3A). The Cq values were lower for the three highest dilutions $(P<0.040)$. After 1,000 -fold dilution, the extraction method had no effect on quantification. The standard curves prepared from the DNA samples extracted with the protocol had lower amplification efficiencies compared to the commercial kit (Figure 1A). It is possible that the qPCR protocol in Abraham et al. (2018) is not optimal for the samples extracted with the developed DNA extraction protocol. However, the extraction method did not affect target detection. 
A

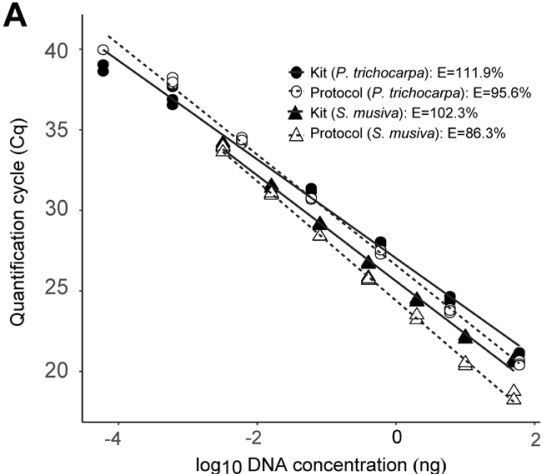

C

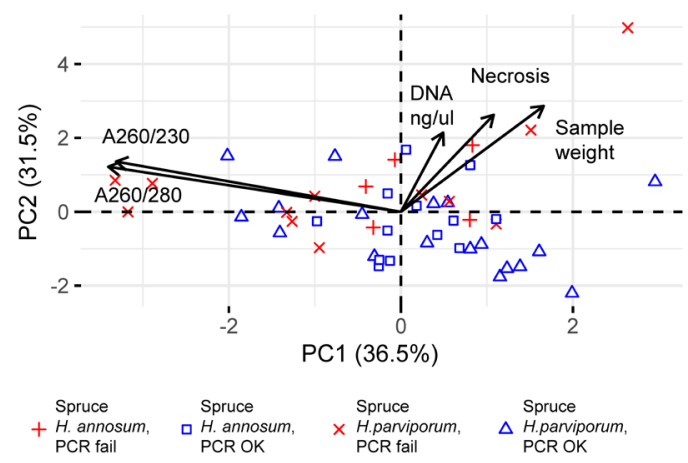

B

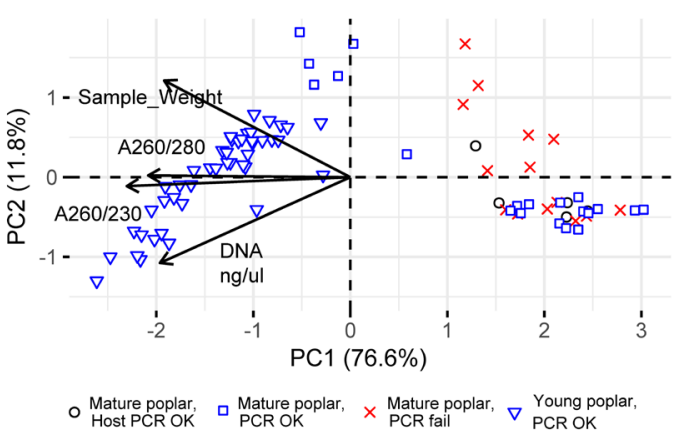

D

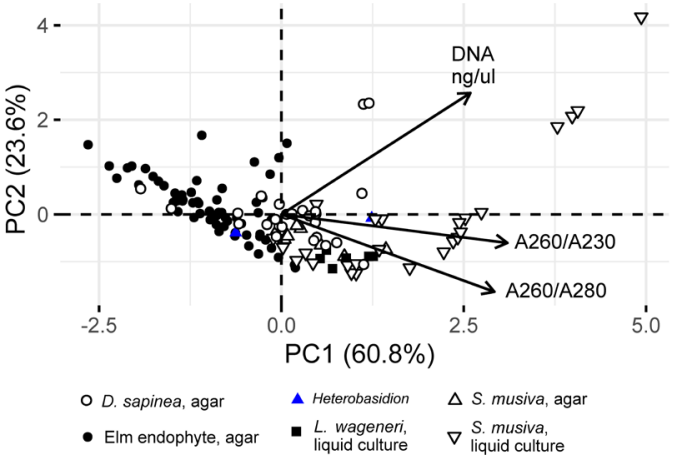

Figure 3. Comparative qPCR analysis to estimate the presence of sample inhibitors (A), and principal component analysis to visualize sample properties in Populus trichocarpa samples (B), young Picea abies samples (C), and fungal samples (D)

We explored the association of DNA sample properties with PCR success by visualizing the results from principal component analysis (PCA). The two first principal components (PC) explained $68-87 \%$ of the total variation. The $\mathrm{A}_{260 / 280}$ and $\mathrm{A}_{260 / 230}$ values explained majority of variation along PC1 for $P$. trichocarpa, $P$. abies, and fungal DNA samples (55\%, $85 \%$ and $75 \%$ contribution to PC1 variation, respectively) (Figures 1B-1D). For P. trichocarpa, the samples split into two groups on both sides of the vertical PC2 axis (Figure 3B). For the samples on the left side of the PC2 axis, PCR success rate was $100 \%$ and sample purity was relatively high (Figure 3B).

Sample weight explained $55 \%$ and $40 \%$ of the variation along the PC2 in P. trichocarpa and $P$. abies, respectively. Larger initial sample weights were associated with lower PCR success rate for mature poplar and young Norway spruce DNA samples (Table 4). Among the 34 mature poplar samples that clustered on the right side of PC2 axis (Figure $3 \mathrm{~B}$ ), initial sample weights and DNA concentrations were higher for the failed PCR reactions $(t=2.882, P=0.007$ and $t=2.195, P=$ 0.035 , respectively). Similarly, initial sample weights and DNA concentrations were higher for $P$. abies samples that failed PCR amplification $(t=1.9511, P=0.057$ and $t=2.060, P=0.045$, respectively). For the mature poplar samples, PCR failure both for host and pathogen amplification despite higher DNA concentration is probably associated with low template quality combined with high polyphenolic content in the mature bark tissue samples. For Norway spruce, PCR failure for pathogen amplification despite high DNA concentration and sufficient template quality is probably 
explained by low amount of pathogen DNA in less colonized samples. Alternatively, high phenolic content in heavily colonized samples may have inhibited pathogen detection, as increasing necrosis length was associated with lower PCR success in Norway spruce samples. This indicates that DNA samples extracted from tree tissue samples with high amounts of lignin or other polyphenolic compounds may have lower PCR success rates.

The fungal DNA samples were highly variable based on $A_{260 / 230}$ and $A_{260 / 280}$ values ( $75 \%$ of variation on PC1, Figure 3D). The DNA samples extracted from mycelium grown in liquid cultures typically had higher measures of purity compared to fungal samples with agar (Table 4). Based on this, we recommend minimizing the amount of agar in the fungal samples used for DNA extractions. Despite high variation in sample purity, PCR amplification was successful for all the fungal DNA samples. 
Please cite this article as: Keriö et. al., (2020). Safe DNA-extraction Protocol Suitable for Studying Tree-fungus Interactions,Bio-protocol 10 (11): e3634. DOI:

10.21769/BioProtoc.3634.

\section{bio-protocol}

www. bio-protocol.org/e3634

Bio-protocol 10(11): e3634.

DOI:10.21769/BioProtoc. 3634

Table 4. Sample weight, DNA concentrations, and DNA absorbance values for different DNA sample types extracted with the protocol. Median, minimum and maximum values are indicated.

\begin{tabular}{|c|c|c|c|c|c|c|c|c|}
\hline \multirow{2}{*}{ Sample type } & \multicolumn{2}{|c|}{ Sample (weight, mg) } & \multicolumn{2}{|c|}{ DNA (ng/ $\mu \mathrm{l})$} & \multicolumn{2}{|l|}{$A_{260 / 280}$} & \multicolumn{2}{|l|}{$A_{260 / 230}$} \\
\hline & Median & Min-Max & Median & Min-Max & Median & Min-Max & Median & Min-Max \\
\hline Young poplar, PCR OK & 100 & 100 & 22 & $11-49$ & 2.2 & $1.6-2.2$ & 1.8 & $1.1-2.1$ \\
\hline Mature poplar, PCR OK & 20 & $10-160$ & 3 & $1-15$ & 1.6 & $0.9-2$ & 0.5 & $0.2-1.2$ \\
\hline Mature poplar, PCR fail* & 35 & $15-140$ & 7 & $1-20$ & 1.3 & $1.2-2$ & 0.4 & $0.3-0.6$ \\
\hline Young spruce, PCR OK & 92 & $36-380$ & 30 & $5-266$ & 1.5 & $0.7-2$ & 0.5 & $0.1-2$ \\
\hline Young spruce, PCR fail** & 136 & $58-326$ & 63 & $10-265$ & 1.6 & $1.2-2.2$ & 0.8 & $0.3-2.2$ \\
\hline Fungal, liquid medium & NA & NA & 35 & $5-330$ & 2.1 & $1.8-2.2$ & 1.7 & $1.1-2.2$ \\
\hline Fungal, solid medium & NA & NA & 20 & $2-168$ & 1.8 & $0.9-2.2$ & 0.5 & $0.1-2.2$ \\
\hline
\end{tabular}

*Both host and pathogen PCR failed

**Only pathogen PCR tested 


\section{Notes}

1. Amount of extraction buffer and sample weight

We recommended to use $1 \mathrm{ml}$ of extraction buffer per $50 \mathrm{mg}$ or less of plant or fungal tissue. Low buffer volume relative to extracted tissue can have a negative effect on PCR success.

2. Dissolving the pellet

If the DNA pellet is not colorless or white post $70 \%$ ethanol wash, add $20-50 \mu$ of TE buffer or nuclease-free water to resuspend the DNA without disturbing the pellet. Gently pipet the liquid a few times in the tube and collect the supernatant as DNA for downstream processes. Keep the pellet until DNA is quantified. Use the DNA for PCR-based detection, or store in freezer until used.

3. Re-using the bead beater tubes

To reduce costs and plastic waste, the bead beater tubes can be washed, treated with bleach to degrade DNA, autoclaved, and re-used. Separate the beads, caps and tubes in separate containers. Fill the containers with warm soap water, agitate for $5 \mathrm{~min}$, and pour out the soap water. Rinse with tap water until runoff is clear. Shake tubes and caps to remove remaining tap water. Rinse twice with DI-water. To remove any remaining DNA, soak the components $1 \mathrm{~h}$ in $3 \% \mathrm{w} / \mathrm{v} \mathrm{NaOCl}$ solution (1:1 solution with commercial bleach and DI-water) (Kemp and Smith 2005). Rinse twice with tap water, followed by two DI-water rinses. Let the tube components dry overnight, or dry in an oven. Once the components are dry, compile the tubes and autoclave at $121^{\circ} \mathrm{C}$ for $30 \mathrm{~min}$.

\section{$\underline{\text { Recipes }}$}

1. Extraction buffer

$1 \mathrm{M} \mathrm{NaCl}$

$100 \mathrm{mM}$ Tris $\mathrm{HCl}$

10 mM EDTA

2\% PVP

a. Mix all ingredients in a beaker on a stirring hot plate

b. Fill to desired volume with sterile purified water

c. Heat the solution until PVP is dissolved

2. Wash buffer

$1 \%$ SDS

$0.5 \mathrm{M} \mathrm{KCl}$ or $\mathrm{NaCl}$

a. Mix all ingredients in a beaker on a stirring hot plate

b. Fill to desired volume with sterile purified water

c. Heat the solution until no precipitation is visible

d. Heat the wash buffer before use to dissolve any precipitants 


\section{Acknowledgments}

This research was supported by the DOE Office of Science, Office of Biological and Environmental Research (BER), grant no. DE-SC0018196, and by funding from the Faculty of Forest Sciences and Forest Ecology, University of Göttingen. Jumoke Aduke Babalola and David Robert Răscuţoi, University of Göttingen, are highly acknowledged for their contribution to the DNA extraction and PCR experimental set up. Dr. Patrick Bennett is thanked for providing the $L$. wagenerii strains and naturally infected Douglas-fir root samples, and Dr. Kelsey Søndreli for providing the mature $P$. trichocarpa samples naturally infected with S. musiva.

\section{Competing interests}

No competing interests declared.

\section{References}

1. Abraham, N. D., Chitrampal, P., Keriö, S. and LeBoldus, J. M. (2018). Multiplex qPCR for detection and quantification of Sphaerulina musiva in Populus stems. Plant Pathol 67(9): 18741882.

2. Arnold, A. E., Maynard, Z. and Gilbert, G. S. (2001). Fungal endophytes in dicotyledonous neotropical trees: patterns of abundance and diversity. Mycol Res 105(12): 1502-1507.

3. Carbone, I. and Kohn, L. M. (1999). A method for designing primer sets for speciation studies in filamentous ascomycetes. Mycologia 91(3): 553-556.

4. Chabi Sika, K., Kefela, T., Adoukonou-Sagbadja, H., Ahoton, L., Saidou, A., Baba-Moussa, L., Jno Baptiste, L., Kotconi, S. O. and Gachomo, E. W. (2015). A simple and efficient genomic DNA extraction protocol for large scale genetic analyses of plant biological systems. Plant Gene 1: 43-45.

5. Chi, M. H., Park, S. Y. and Lee, Y. H. (2009). A quick and safe method for fungal DNA extraction. Plant Pathol J 25: 108-111.

6. Chiong, K. T., Damaj, M. B., Padilla, C. S., Avila, C. A., Pant, S. R., Mandadi, K. K., Ramos, N. R., Carvalho, D. V. and Mirkov, T. E. (2017). Reproducible genomic DNA preparation from diverse crop species for molecular genetic applications. Plant Methods 13(1): 106.

7. Edwards, K., Johnstone, C. and Thompson, C. (1991). A simple and rapid method for the preparation of plant genomic DNA for PCR analysis. Nucleic Acids Res 19(6): 1349.

8. Gardes, M. and Bruns, T. D. (1993). ITS primers with enhanced specificity for basidiomycetes-application to the identification of mycorrhizae and rusts. Mol Ecol 2(2): 113-118.

9. Grünig, C. R., Brunner, P. C., Duo, A. and Sieber, T. N. (2007). Suitability of methods for species recognition in the Phialocephala fortinii-Acephala applanata species complex using DNA analysis. Fungal Genet Biol 44(8): 773-788. 
10. Hantula, J. and Vainio, E. (2003). Specific primers for the differentiation of Heterobasidion annosum (s.str.) and H. parviporum infected stumps in northern Europe. Silva Fennica 37.

11. Higgins, K. L., Arnold, A. E., Miadlikowska, J., Sarvate, S. D. and Lutzoni, F. (2007). Phylogenetic relationships, host affinity, and geographic structure of boreal and arctic endophytes from three major plant lineages. Mol Phylogenet Evol 42(2): 543-555.

12. Kassambara, A., and Mundt, F. (2017). factoextra: Extract and visualize the results of multivariate data analyses.

13. Kemp, B. M. and Smith, D. G. (2005). Use of bleach to eliminate contaminating DNA from the surface of bones and teeth. Forensic Sci Int 154(1): 53-61.

14. LeBoldus, J. M., Blenis, P. V. and Thomas, B. R. (2010). A method to induce stem cankers by inoculating nonwounded Populus clones with Septoria musiva spore suspensions. Plant Dis 94(10): 1238-1242.

15. Lu, Y. (2011). Extract genomic DNA from Arabidopsis leaves (can be used for other tissues as well). Bio-protocol 1(13): e90.

16. Nelsen, M. P., Lücking, R., Mbatchou, J. S., Andrew, C. J., Spielmann, A. A. and Lumbsch, H. T. (2011). New insights into relationships of lichen-forming Dothideomycetes. Fungal Diversity 51(1): 155-162.

17. Porebski, S., Bailey, L. G. and Baum, B. R. (1997). Modification of a CTAB DNA extraction protocol for plants containing high polysaccharide and polyphenol components. Plant Mol Biol Rep 15(1): 8-15.

18. Saini, H. S., Shepherd, M. and Henry, R. J. (1999). Microwave extraction of total genomic DNA from barley grains for use in PCR. $J$ Inst Brew 105(3): 185-190.

19. Schweigkofler, W., W.J, O., S.L, S., D.R, C., Maeda, K., Peay, K. and Garbelotto, M. (2005). Detection and quantification of Leptographium wageneri, the cause of black-stain root disease. from bark beetles (Coleoptera: Scolytidae) in Northern California using regular and real-time PCR. Canadian Journal of Forest Research 35: 1798-1808.

20. Terhonen, E., Langer, G. J., Bußkamp, J., Răscuţoi, D. R. and Blumenstein, K. (2019). Low water availability increases necrosis in Picea abies after artificial inoculation with fungal root rot pathogens Heterobasidion parviporum and Heterobasidion annosum. Forests 10(1): 55.

21. Terhonen, E., Marco, T., Sun, H., Jalkanen, R., Kasanen, R., Vuorinen, M. and Asiegbu, F. (2011). The effect of latitude, season and needle-age on the mycota of Scots pine (Pinus sylvestris) in Finland. Silva Fenn 45

22. Vilgalys, R. and Hester, M. (1990). Rapid genetic identification and mapping of enzymatically amplified ribosomal DNA from several Cryptococcus species. J Bacteriol 172(8): 4238-4246.

23. White, T., Bruns, T., Lee, S., Taylor, J., Innis, M., Gelfand, D. and Sninsky, J. (1990). Amplification and direct sequencing of fungal ribosomal RNA genes for phylogenetics. In: PCR Protocols, Academic Press, Inc., pp. 315-322.

24. Winton, L. M., Stone, J. K., Watrud, L. S. and Hansen, E. M. (2002). Simultaneous one-tube quantification of host and pathogen DNA with real-time polymerase chain reaction. 
Phytopathology 92(1): 112-116.

25. Yi, S., Jin, W., Yuan, Y. and Fang, Y. (2018). An optimized CTAB method for genomic DNA extraction from freshly-picked pinnae of fern, Adiantum capillus-veneris L. Bio-protocol 8(13): e2906. 